\title{
港内の河口域近辺に発生する流れについての海洋環境調査
}

\author{
神田侑希 ${ }^{1}$. 千葉元 ${ }^{2}$ ・吉田将司 ${ }^{3}$ ・島崎清寿 ${ }^{4}$
}

\section{Ocean Environmental Survey on Influence of River Inflows on Current within a Harbor}

\author{
Yuki KANDA ${ }^{1}$, Hajime CHIBA $^{2}$, Masashi YOSHIDA ${ }^{3}$ and Kiyohisa SHIMAZAKI ${ }^{4}$
}

\begin{abstract}
The waters facing the Marine Training and Research Center (MTRC) at the National Institute of Technology (NIT), Toyama College consist of a mixture of inflows from the Shinbori River, a timber pond and the open sea. In this study, we examine a particular current that is influenced by the combination of inflows and open seawater occurred in summer. This slow current, which flows westward at the speed of approximately $0.1-0.3 \mathrm{~m} / \mathrm{s}$, influences handling of small boats and the college training ship Wakashio-maru (231 GT) that operate from the MTRC pier. Accordingly, the authors conducted Conductivity, Temperature and Depth profiler (CTD), Electromagnetic current meter, and Acoustic Doppler Current Profiler (ACDP) observations of the marine environment of the flow in order to gain an understanding of the inflow waters such as their vertical formulations, seasonal variations, water structure, temperature, and salinity. The results of those observations revealed that the waters consisted of three layers, with the upper layer most influenced by the Shinbori River and the lower layer most influenced by the open sea. The middle layer was a mixture of both the upper and lower layers. It was also found that the borders of layers changed according to seasons, and that the flow was influenced by the tidal current at lower layer, the river water at upper layer and the topography.
\end{abstract}

Keywords : Navigation and earth environment, $C T D, A D C P$, Tidal current, Water mass structure キーワード：航海・地球環境、CTD、ADCP、潮流、水塊構造

\section{1. はじめに}

富山高等専門学校臨海実習場 (以下、臨海実習 場とする。が、2015 年 3 月に、Fig.1(a),(b)に示寸 富山湾沿岸部の富山新港入口付近から、南部の東 水路奥部に移転した。この臨海実習場の前面海域 は、富山湾からの流入海水と、Fig.1(b)に示寸、近 隣にある新堀川や貯木場からの低塩分水が混在し ている。ここで、夏場において、この外海水と低 塩分水の共存影響と思われる、特異な流れが発生 することが、しばしば見受けられた。具体的な状 況としては、西向きの流れが発生して、カッター 等の微速で航走する小型舟艇が、設定針路よりも 西一偏向する影響を受けていた。また、富山高専 の練習船「若潮丸」(231t) が離岸の際、最後の係 留索の張具合が強くなるといった影響が出ていた。
これらの流速は、こうした状況より $0.1 \sim 0.3 \mathrm{~m} / \mathrm{s}$ 程度と思えるが、小型舟艇の航行や大型船舶の離 着岸等の微速航行の際の影響は無視できないもの である。そこで、この海域の水塊構造や流れの海 洋環境調査を行い、この海域に発生する特異な流 れのメカニズムの解明を試み、臨海実習場船艇の 安全航行に役立てることを目的としている。

この富山新港の外海である富山湾は、対馬暖流 が沿岸部まで流れ込み、その上部に Fig.1(a)に示す ように多くの河川水からの流入水が広がり、これ らが場所的、季節的に変動していく状況が、千葉 らのこれまでの調査 ${ }^{(1),(2),(3)}$ で確認されている。そ して、外海水と河川水が交わる河口域では、双方 の密度差から、エスチュアリー循環を生じ、特異 な流れを発生することが知られている(4)。

1 学生会員 富山高等専門学校 海事システム工学専攻 ms1512402@nc-toyama.ac.jp

2 正会員富山高等専門学校 商船学科 chiba@nc-toyama.ac.jp

3 正会員サレジオ工業高等専門学校 機械電子工学科 4 非会員 富山高等専門学校 技術室 
本論では、こうした知見から、臨海実習場前面 水域における、流れのメカニズムの解明を試みる。

臨海実習場の平面配置図と観測点を Fig.1(c) に 示す。図中の赤丸が水塊構造や流れの鉛直分布と 季節変動特性の定点観測を行った、検潮室（Tide station）及び浮栈橋（Floating pier）である。この 海域の水深は、西側は約 6〜8m、東側では約 4〜 $6 \mathrm{~m}$ である。しかし、浮栈橋の東側は、土砂等の 堆積により約 $2 \mathrm{~m}$ 以下と非常に浅くなっている。 この浮栈橋は、小型船でも航行困難な浅海部との 境界を、水面に明確に示すため設置された。

\section{2.実地観測及び結果}

\section{1 観測（固定点の電磁式流速計観測）}

この臨海実習場の検潮室には、練習船「若潮丸」 の入港支援を主目的として設置された、電磁式流向 流速計 (JFE Advantech : INFINITY-EM、以下 EM current meterとする。）がある。この観測值は、臨 海実習場内のPCでリアルタイムにモニターされ、 データ記録も行っている。この流速測定は、海水が 移動することによりセンサー中の磁束に生じる誘起 電圧の変化から行い、このセンサーが直交して2軸 あることにより、2つのベクトルより流向を求めて いる。絶対流向を算出する基準は、内蔵されている 地磁気センサーである。検潮室の海側の空より、手 動によりセンサーを任意の水深に設置し、ここでの 絶対流向流速を測定することが可能である。まずは、 この EM current meter により、この実習場近辺の 流れの鉛直分布、潮汐・風・河川水等との関係も把 握を試みた。併せて、同時点で流れを起こす要因分 析のために、CTD (Conductivity, Temperature and Depth profiler, JFE Advantech : RINKO-Profiler)観 測を行い、水温・塩分等の鉛直分布把握を試みた。 この機器は、圧力・温度・電気伝導度センサーを搭 載し、これから各水深の水温・塩分等の算出を行っ ている。これらの使用機器の主要目と観測範囲と精度 を、Table1に示す。EM current meter は、流向流速 の傾向の鉛直分布を知るために、センサー部分を表 層の $0.3 \mathrm{~m}$ 深から $8 \mathrm{~m}$ 深まで、 $1 \mathrm{~m}$ 毎に移動させて観測 した。各水深では、5分間の観測を行った。データ 取得間隔は1秒である。CTDは、手動でロープを操 作して、海面から海底まで垂直に降下し計測した。 ここでは深度トリガーを $0.1 \mathrm{~m}$ に設定しての観測を 行っている。深度のFSは600mで、センサーの水中 投入時に深度の零点調整を実施している。

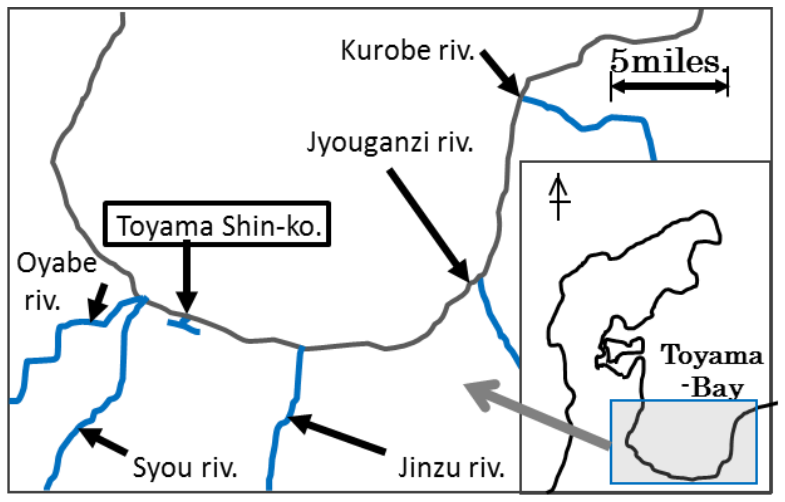

(a) Location of Toyama Shin-ko. and five big rivers, at the coast of Toyama Bay.

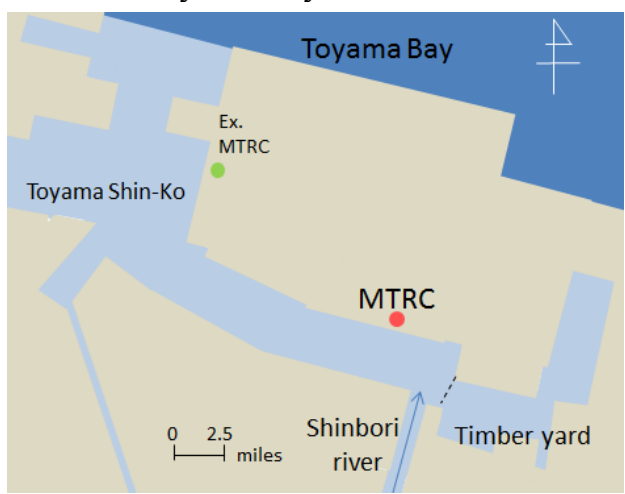

(b) Ex.(green point) and current(red point) locations of MTRC, NIT, Toyama College at Toyama Shin-ko.

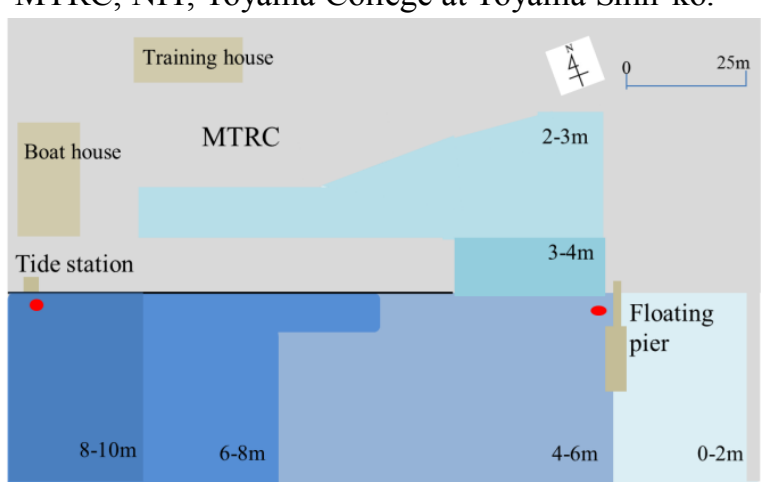

(c) Arrangement of the facilities of MTRC and the observation points (red points) of this study, and the water depth contours by meters, and the shallow $\sim$ deep blue areas means sea area with the depth.

Fig .1 Location of Marine Training and Research Center (MTRC), NIT, Toyama College and the observation points, "Tide station" and "Floating pier".

Table 1 Outline of EM current meter and CTD.

(i) EMcurrent meter (JFEAdvantech Co: : INFINITY-EM)

\begin{tabular}{|c|c|c|}
\hline Items & Range & Mesurement accuracy \\
\hline Current speed & $0 \sim \pm 500 \mathrm{~cm} / \mathrm{sec}$ & $\pm 1 \mathrm{~cm} / \mathrm{sec}$ or $\pm 2 \%$ \\
\hline Direction & $0 \sim 360^{\circ}$ & $\pm 2^{\circ}$ \\
\hline Water temperature & $-5 \sim 45^{\circ} \mathrm{C}$ & $\pm 0.02^{\circ} \mathrm{C}$ \\
\hline
\end{tabular}

(ii) CTD (JFE Advantech Co. :RINKO-Profiler)

\begin{tabular}{|c|c|c|}
\hline Items & Range & Mesurement accuracy \\
\hline Depth & $0 \sim 600 \mathrm{~m}$ & $\pm 0.3 \% \mathrm{FS}$ \\
\hline Water temperature & $-5 \sim 40^{\circ} \mathrm{C}$ & $\pm 0.01^{\circ} \mathrm{C}\left(0 \sim 35^{\circ} \mathrm{C}\right)$ \\
\hline Electric conductivity & $0 \sim 70 \mathrm{mS} / \mathrm{cm}$ & $\pm 0.01 \mathrm{mS} / \mathrm{cm}$ \\
\hline
\end{tabular}


この観測を 2015 年 10 月から 2016年 6 月にかけ て実施してきたが、Fig.2 に冬季、Fig.3 に春季に おける観測結果例を示す。この観測を実施した日 時、気象海象状況を Table2 に示す。ここで、気温 と風向風速は臨海実習場設置の観測機器、波浪の 状況は目視で行った。潮汐の時間帯については、 気象庁による富山新港の予測值を使用している(5)。

Fig.2では EM current meterによる (a) Current velocity, (b) Current direction の 2015 年 12 月 15 日 の観測結果を、縦軸のセンサー部の各設置水深に おけるデータをプロットしている。(c) Scattered diagram では、 $0.5 \mathrm{~m}$ 深と $6 \mathrm{~m}$ 深における、流向と 流速観測值の散布図を示している。そして、CTD 観測による(d) Temperature, (e) Salinity, (f) Density の鉛直プロファイルを示している。これらの CTD 観測值については、同時季の変動状況の比較のた めに、同年 12 月 8 日のデータも示している。

Fig.2(a),(b),(c)に示す流れについては、0.3m深に おいては、流速が約 0.0 約 $0.1 \mathrm{~m} / \mathrm{s}$ 程度、流向が 約 $\mathrm{N} \sim \mathrm{E} 、 \mathrm{NW} \sim \mathrm{N}$ においてばらついている。ここ で、流向 $\mathrm{N} \sim \mathrm{E}$ の流れは、この時が $\mathrm{SW}$ 方向の風 であったので、表層部における吹送流が発達した ものと思える。そして、これとは別に NW〜N 方 向の流れも存在し、Fig.2(d),(e)に示寸 CTD 観測結 果と比較すると、水深約 $1 \mathrm{~m}$ までは低水温・低塩 分層が存在しており、河川水影響による流れと思 える。これらの表層部の流れは、Fig.2(a),(b)に示 寸ように、流速が約 $0.02 \mathrm{~m} / \mathrm{s}$ 以下に非常に弱くな るが、1 $\mathrm{m}$ 深まで続き、2〜 $5 \mathrm{~m}$ 深においては、流速 が約 $0.04 \sim 0.06 \mathrm{~m} / \mathrm{s}$ 、流向が $\mathrm{E} \sim \mathrm{NNE}$ の範囲となっ ている。この深度範囲では、流速が非常に弱く、 流向が不安定である。しかし、6 $\mathrm{m}$ 深において、流 速は約 $0.0 \sim 0.02 \mathrm{~m} / \mathrm{s}$ 以下と非常に弱いが、Fig. 2 の (c) Scattered diagram に示寸通り流向が E〜SSE の 範囲となり、ESE に強く分布している。

Fig.2(d),(e)の CTD 観測結果を見ると、Table1 に 示寸 12 月は気温が $14 \sim 18^{\circ} \mathrm{C}$ であり、表層の水温 が近い值になっているのが分かる。そして、水深 が 2 3m までは温度・塩分共に水深に伴って急に 増加し、この変化が 5〜 6m深までは緩やかとなり、 これ以深では一定となる傾向がある。CTD 観測に
おける 6〜 8m深の塩分は、富山湾沿岸部の水深約 $30 \mathrm{~m}$ 以深の観測值 ${ }^{(6)}$ である、約 33.5〜34.5 に近い 数值である。これより、港外の高塩分水とつなが る深部にて、Fig.2 (f) Densityに示す表層より高い 密度（ $\sigma$ で約 23.8〜 24.4）の水塊で、潮汐影響が 強いことが推測できる。そして、干潮から満潮の 上げ潮時では、この富山新港東水路では東向きと なる、港口から港奥に向かう流れとなると思える。 従って、6 $\mathrm{m}$ 深の流れは潮汐影響による、上げ潮 の東流と判断している。この深部の潮汐に伴う流 れは、Fig.2(d),(e),(f)に示す、12月 8 日と 15 日の CTD 観測結果が類似した傾向を示すように、冬場 に共通した現象であった。

こうして、この水域の水塊構造は、表層の河川 水影響が強い水塊、底部の外海からの海水の影響 が強い層、そして表層部と底部間の混合領域の 3 層構造と定義できる。そして、この境界線が、約 1〜3m深, 5〜 6m深である。この境界は、Fig.2 (a), (b) に示した、流れの傾向変化の境界線とも一致 するものである。

Fig.3 は Fig.2 と同様に、2016 年 5 月 9 日の観測 結果を示している。Fig.3(d),(e),(f)に示す CTD デー タでは、冬季との比較のために、Fig.2で用いた 12 月 15 日のデータも示している。まず、 $0.3 \mathrm{~m}$ 深 においては、Fig.3(c) Scattered diagramより、流速 が約 $0.04 \sim$ 約 $0.16 \mathrm{~m} / \mathrm{s}$ 程度、流向が約 $\mathrm{W} \sim \mathrm{NNW}$ の 流れが確認できる。これが、カッターを西向きに偏 向させる流れとなっていた。この春季より、この 西向きの流れが頻繁に発生するようになり、夏季 により顕著になっていく。そして、1〜3m深では、 表層とは逆方向の東向きの流れとなっている。Fig.3 の(c) Scattered diagramにて $2 \mathrm{~m}$ 深では、流速約 0.02 $\sim 0.06 \mathrm{~m} / \mathrm{s}$ で、流向 E〜SE となっている。これは、

Fig. 2 における $6 \mathrm{~m}$ 深の流れと同様、上潮に伴う港 口から港奥に向から流れであり、潮流影響と判断で きる。この流れは 1〜3m 深においては、流速が約 $0.04 \sim 0.06 \mathrm{~m} / \mathrm{s}$ 、流向が $\mathrm{E} \sim \mathrm{NNE}$ の範囲となってい る。また、4〜 $8 \mathrm{~m}$ 深では、流速が約 $0.02 \mathrm{~m} / \mathrm{s}$ 以下 と非常に弱く、このため流向も不安定である。

ここで、CTD 観測結果を見ると、4〜 5 月で気温 が上昇し、新堀川からの流量も増えるので、Fig.3

Table 2 Date and weather, wave and tide conditions at the observations of EM current meter.

\begin{tabular}{|l|c|c|c|c|c|c|}
\hline & Time & Wind direction & Wind speed & Air temp. & Wave & Tide \\
\hline Dec.15,2015 & $13: 20 \sim 13: 55$ & SW NW & $3.0 \sim 4.0 \mathrm{~m} / \mathrm{s}$ & $14^{\circ} \mathrm{C}$ & Very smooth & Low $(12: 00,5 \mathrm{~cm}) \rightarrow H i g h(18: 00,26 \mathrm{~cm})$ \\
\hline May 9,2016 & $11: 40 \sim 12: 25$ & North & $4.0 \mathrm{~m} / \mathrm{s}$ & $17^{\circ} \mathrm{C}$ & Very smooth & Low $(11: 00,15 \mathrm{~cm}) \rightarrow \operatorname{High}(15: 00,28 \mathrm{~cm})$ \\
\hline
\end{tabular}


(d) Temperature より表層水温が上昇し、(e) Salinity より表層塩分が低下しているのが分かる。表層の 塩分は約 8〜10 であり、河川水影響が非常に強い ことが分かる。この水温と塩分が鉛直方向に急激 な変化をしている境界線は、1～2m深であると言 える。また、特に水温は $5 \mathrm{~m}$ 深まで降下を続け、 これ以深では一定となる。塩分も、2～5 m深まで 緩やかな上昇を行い、 $5 \mathrm{~m}$ 以深では一定となってい る。ここで、(f) Density で確認すると、1〜2m深、 4〜 $5 \mathrm{~m}$ 深で密度変化の境界があることが分かる。 こうして、この水域の水塊構造は、表層の河川水 影響が強い水塊、底部の外海からの海水の影響が 強い層、そして表層部と底部間の混合領域、の 3 層構造と定義できる。そして、この境界線が、約 1〜2m深，4～5 m深である。この境界は、Fig.3 (a), (b) に示した、流れの傾向の境界線とも一致する ものである。但し、冬季と春季の 3 層構造を比較 すると、春季は表層が高温・低塩分で成層してい るために、この下部の混合層は、底部の海水と密 度が近い海水となっている。CTD 観測における、 5 月 9 日の $2 \sim 8 \mathrm{~m}$ 深の塩分は、冬季と同様に、富 山湾沿岸部の水深約 $30 \mathrm{~m}$ 以深の観測值 ${ }^{(6)}$ である、 約 33.5 34.5に近い数值である。これより、この 層において、潮汐影響が強いことが推測できる。

ここで、Fig.3(f) Density のグラフで、12月 15 日と 5 月 9 日を比較したものにおいて、12月 15 日の潮汐影響が大きい $6 \mathrm{~m}$ 以深での密度は約 23.8 〜24.4で、一定であり、この上層では密度が緩や かに低下している。 5 月 9 日では、約 2 $4.5 \mathrm{~m}$ 深 では密度が約 24.5〜25.2、約 4.5 8 $\mathrm{m}$ 深では密度 が約 25.5 までに上昇している。そして、約 $2 \mathrm{~m}$ 以 浅では密度が急激に下降している。5 月9 日のよ うに春季においては、中間層において、潮汐影響 による流れの影響が顕著になっている。これは、 港外と港内の、成層状況や鉛直混合の状況の差異 による、密度差のバランスより、この中間層にお いて、潮汐影響の流れが起こりや寸く、その下層 で流れが澱む状況になっているものと思える。こ の海域では、春季になり、河川水の流入量が上が ると同時に、土砂や栄養塩の流入量も増加してい る。こうしたことで、底部では土砂や植物プラン クトン、またその死骸等の影響で流れにブレーキ がかかっていることも推測できる。

こうした結果より、この海域は河口域としての エスチュアリー循環の特性 ${ }^{(4)}$ を持っていることが
判明した。下層は外海と近い温度・塩分であり、 これは潮汐に伴い、約 $0.05 \sim 0.1 \mathrm{~m} / \mathrm{s}$ 以下の非常に 弱い流れであるが干潮から満潮時には東向き、満 潮から干潮は西向きの流れとなっていることが分 かった。また、上層は河川水や風の影響で、下層 とは異なる流れとなっていることが確認された。 特に、春から夏場にかけては、上層に低密度の海 水が成層し、この水塊が動きや寸くなっているこ とが推測される。

\section{2 観測（ADCP による流れの鉛直分布の連続 観測)}

2.1 において、EM current meter と CTD を用い た観測により、この実習場近辺の流れと水塊構造 の鉛直分布を観測し、潮汐変化や河川水流入との 関連性を考察した。次に、1 日以上の時系列的な 変化傾向を把握するために、超音波式多層流向流 速計 (Acoustic Doppler Current Profiler、以下 ADCP とする。：RDI Workhorse 1200kHz) での連続観測 を行い、この海域の長期的な流れの変動状況の把 握を試みた。この機器は、海底や海面での設置を 行い、鉛直方向に複数の超音波ビームを発射し、 水中の懸濁物質等からの反射波の強度とドップラ ーシフトより、流向及び流速を多層的に計測がで きる。今回使用した ADCP は、 $1200 \mathrm{kHz}$ の周波数 で $0.25 \mathrm{~m}$ の間隔で計測している。Table3 に使用し た $\mathrm{ADCP} の$ 観測範囲と精度を示す。これまで千葉 らは、この機器により富山湾沿岸部で多くの観測を 行い、CTD 観測と併せて流れの現象解析を実施し てきている ${ }^{(6)}$ 。ADCP の設置場所は Fig.1 (c) の “Floating pier”に示す赤点で、岸壁から浮栈橋の渡 り通路から、海底にビームを上向きになるよう固 定設置した。ここで、一番近い壁面や栈橋固定の チェーン等からは数 $\mathrm{m}$ 以上は離れていて、4 本の 各ビームの反射強度状況等を分析して、これらの 反射波による誤差影響が無いことは確認できた。 これまでの海底固定設置により ADCPを用いた観 測から、30〜50ピングでの平均化処理したものを 1 アンサンブルとして、横軸を時間、縦軸を水深 とした、流向流速分布のコンター図を作成して、 この流れの特性の考察を䛊差評価も含めて行う。

そこで、今回は、0.6 秒間隔で 50 ピングの発信 を行い、これを 1 アンサンブルとした。そして、 この 1 アンサンブルを 3 分ごとに実施している。 


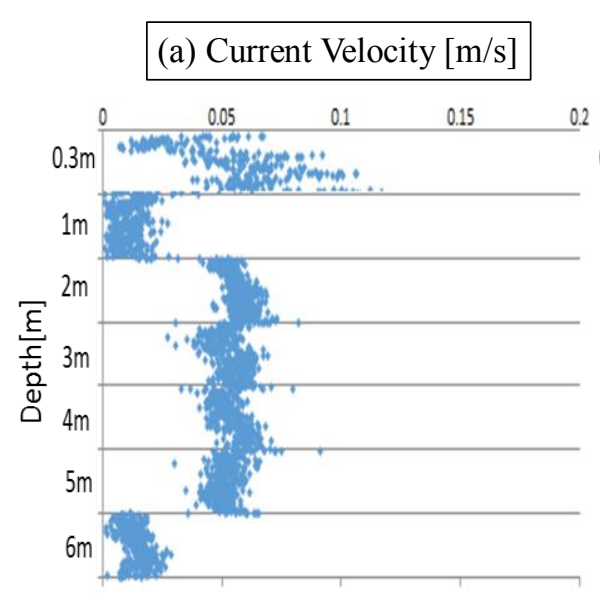

(d) Water temperature $\left[{ }^{\circ} \mathrm{C}\right]$

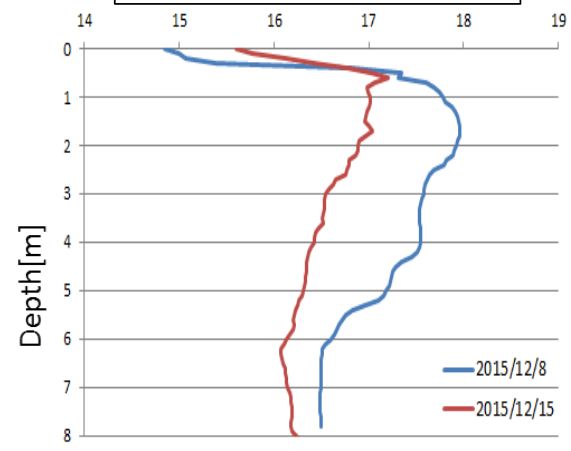

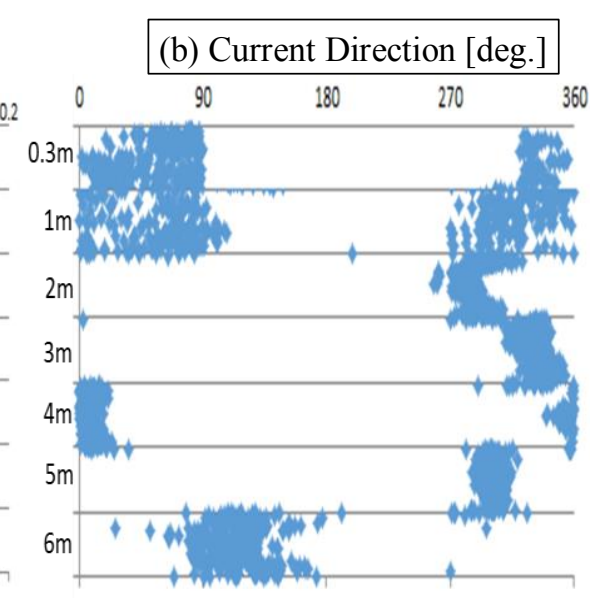

(e) Salinity (psu)

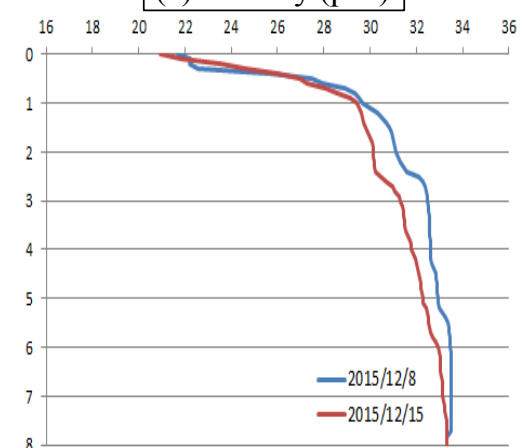

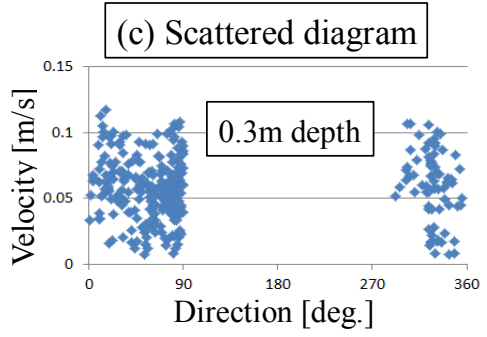

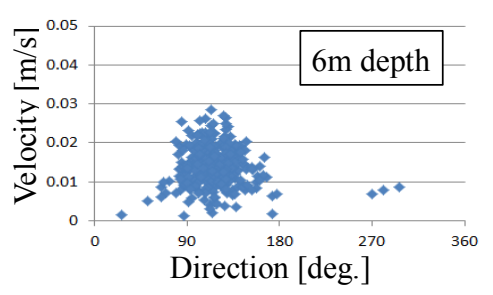

(f) Density ( o )

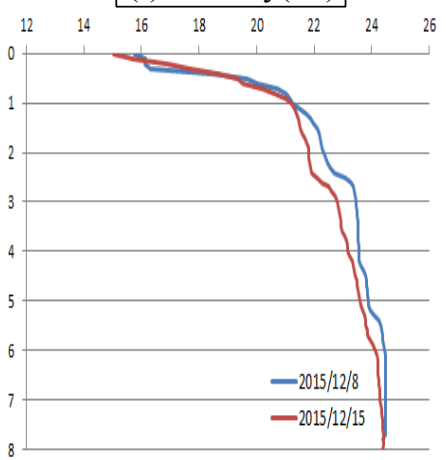

Fig. 2 Measured results of EM current meter((a) current velocity (b) direction and (c) Scattered diagram on Dec.15, 2015) and CTD ((d) Water temperature, (e) Salinity and (f) Density on Dec.8 and 15, 2015), in winter.

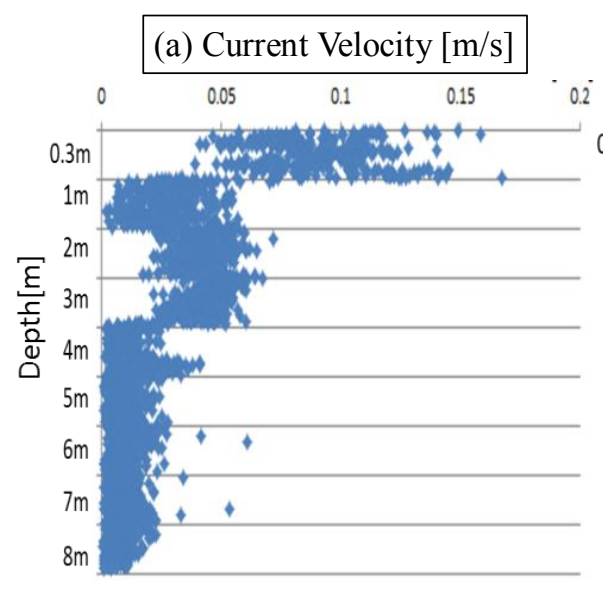

(d) Water temperature $\left[{ }^{\circ} \mathrm{C}\right]$

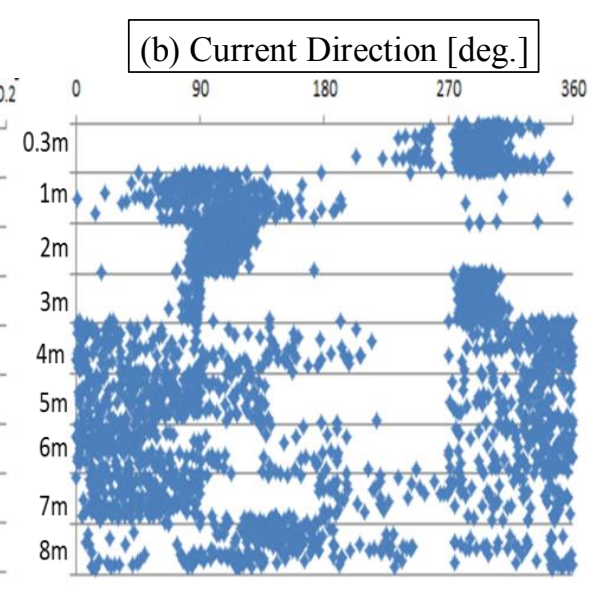

(e) Salinity (psu)

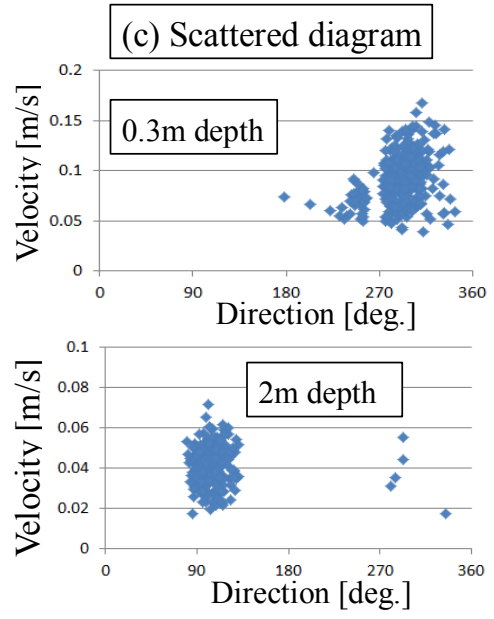

(f) Density ( $\sigma)$
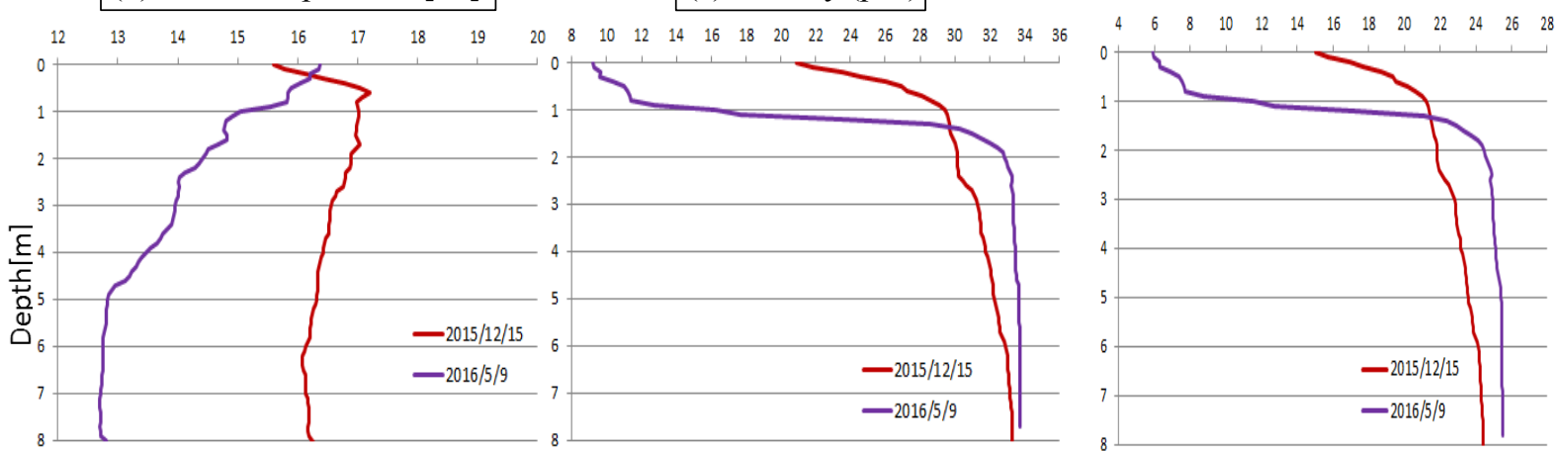

Fig.3 Measured results of EM current meter((a) current velocity (b) direction and (c) Scattered diagram on May.9, 2016) and CTD ((d) Water temperature, (e) Salinity and (f) Density on May 9, 2016, with compare result on Dec. 15,2015 .) in spring. 
ここで、Table3 に示すように、単ピングでの流 速観測の精度が $0.182 \mathrm{~m} / \mathrm{s}$ なので、理論上の 1 アン サンブル観測精度は、 0.182 を 1 アンサンブルのピ ング数（50）の平方根で除した值となるので、 $0.182 \mathrm{~m} / \mathrm{s} /(50)^{1 / 2}=$ 約 $2.57 \mathrm{~cm} / \mathrm{s}$ となる。

Table 3 Outline of ADCP (RDI Workhorse $1200 \mathrm{kHz}$ )

\begin{tabular}{|c|c|}
\hline Items & Range \\
\hline Transmission center frequency & $1200 \mathrm{kHz}$ \\
\hline Constant layer thickness & $0.25 \mathrm{~m}$ \\
\hline Maximum measurement distance & $20 \mathrm{~m}$ \\
\hline Standard deriation at one ping & $0.182 \mathrm{~m} / \mathrm{s}$ \\
\hline
\end{tabular}

\section{(1) ADCP 観測 I (7 月)}

2016 年 7 月 12 日から 15 日にかけて ADCPを浮 栈橋下の海底に設置しての観測を実施した。また、 この ADCP 観測の開始前後に同海域での CTD 観 測を行っている。Fig.4に 12 日 14 時から 13 日 14 時にかけての時間帯を抜粋した ADCP 観測結果と、 CTD 観測による水温・塩分を示す。

$\mathrm{ADCP}$ 観測結果は、横軸を時間として、(a) Current direction は $0 \sim 360^{\circ}$ 、(b) Current velocity は $0 \sim 300 \mathrm{~mm} / \mathrm{s}$ を色分けして示している。縦軸は、 反射強度が強い位置から確定した海面からの水 深を示し、この縦軸を併せて、CTD 観測の (d) Temperature, (e) Salinity を示した。

ここで Fig.4(d),(e)に示す CTD の観測值は、7 月 12 日の $\mathrm{ADCP}$ 観測開始時から 7 月 15 日の $\mathrm{ADCP}$ 観測の終了時の值を示している。これより、この 期間において、水温・塩分の鉛直分布に大きな差 は無く、約 $2 \mathrm{~m}$ 深と約 $4 \mathrm{~m}$ 深を境界とした 3 層構造 であることが確認できる。また、表層の水温が約 $26^{\circ} \mathrm{C}$ まで上昇し、塩分が 16 と低く、夏場の高温と 河川水影響が強く出ていることが確認できる。そ して、(c) Water temperature and Tide level は、ADCP の超音波ビーム発信部に設置された水温センサー （水深約 $6 \mathrm{~m} ） の$ 観測值と、気象庁による富山新 港の水位予測值 ${ }^{(6)}$ を、横軸を同一にして示す。

まず、Fig.4(a),(b)で示す ADCP による流向・流 速の観測結果より、表層において、流速約 0.2〜 $0.3 \mathrm{~m} / \mathrm{s}$ 以上の西向きの流れが顕著だと分かる。そ して下層では、白点線の丸印で示したように流向が 数時間の周期で変化している傾向が伺える。ここで、 干潮から満潮に向かう範囲では、流向が東向きの 傾向であることが分かる。

また Fig.4(c)Water temperature and Tide level で示 す、この時間帯で 2 度目の干潮から満潮へ向かう、 13 日 2 時から 10 時の時間带では、(b) Current velocity の表層の黄色点線丸印で囲った範囲で、 流速が約 $0.2 \sim 0.3 \mathrm{~m} / \mathrm{s}$ に上がっていることが分か る。Fig.4(d),(e)で示す CTD 結果より、この流れが 発生している表層から水深約 $2 \mathrm{~m}$ までは、高温 度・低塩分で成層していることが分かる。これよ り、潮高差が大きく、潮流影響が大きいときに、 上層の密度の低い水が流動を起こしや寸い状況に なっていることが推測される。これは、Fig.1 (c) に 示寸水深が浅くなる浮栈橋近辺の水路端部におい て、下層東流と上層西流の循環が起こっているも のと推測される。また、(c) Water temperature and Tide level より、この満潮時においては、海底付近 の水深センサー部で水温が、約 $1{ }^{\circ} \mathrm{C}$ 程低下してい るのが確認できる。

\section{(2) ADCP 観測 II（8 月）}

次に、2016年 8 月 3 日から 10 日にかけて ADCP を、7 月と同じ場所に設置して観測を行った。Fig.5 では、3 日 20 時から 4 日 8 時の ADCP データを抜 粋して示している。ADCP データの (a) Current direction, (b) Current velocity, (c) Water temperature and Tide level 、CTD データの (d) Temperature, (e)Salinity の表記方法は、Fig.4 と同一である。CTD の観測值は、8 月 3 日の $\mathrm{ADCP}$ 観測開始時から 8 月 10 日の $\mathrm{ADCP}$ 観測の終了時の值を示している。 これより、この期間においては、水温が約 $1 \sim 2{ }^{\circ} \mathrm{C}$ 上昇しているのが分かるが、水温・塩分共に鉛直 分布の変化傾向に大きな差は無い。そして、Fig.4 に示した 7 月と同様に約 $2 \mathrm{~m}$ 深と約 $4 \mathrm{~m}$ 深を境界と した 3 層構造であることが確認できる。ここで、 表層の水温が約 $29^{\circ} \mathrm{C}$ まで上昇し、塩分が 14 と低 く、夏場の高温・低塩分の成層が強化され、河川 水影響が強く出ていることが確認できる。

ここで、 (a) Current direction より、表層部は一様 に西向きの流れが見られ、流速は $0.1 \sim 0.3 \mathrm{~m} / \mathrm{s}$ の速 さがある。これは CTD 観測による水温・塩分より、 表層から水深約 $2 \mathrm{~m}$ までの成層の範囲と一致して いる。しかし、この下層の流れの、数時間周期での流 向変化は、Fig.4 の場合に比べて顕著で無く、潮流 との相関性が確認できないこここで、Fig.4 (b) と Fig.5 (b) に示寸流速分布を詳細に確認寸ると、ほぼ一 定の流向が確認できる流速の閾值が、約 $5 \mathrm{~cm} / \mathrm{s}$ 以 上であることが分かった。元々、こうした弱い流 速に対しては、先に示した理論上は約 $2.57 \mathrm{~cm} / \mathrm{s}$ の 観測精度の状況では、これらのコンター図での把 


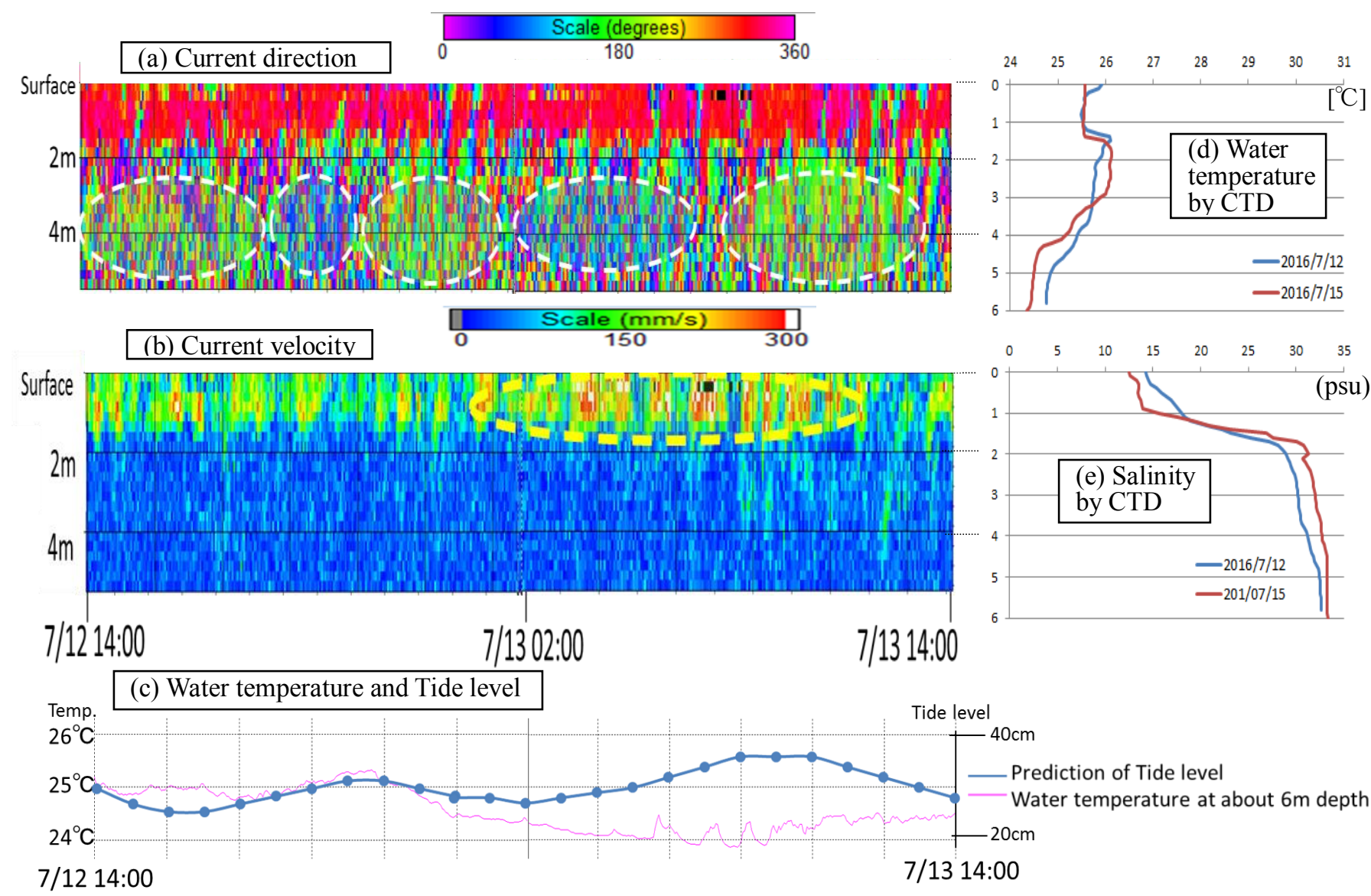

Fig.4 (Left) Measured results of ADCP, (a) Current direction, (b) Current velocity and (c) Water temperature, compared with predicted water level by Japan Metrological Agency (JMA) ${ }^{(5)}$, July 12-13, 2016. (Right) Vertical profiles of (d) Water temperature and (e) Salinity by CTD measurement on July 12 and 15, 2016, start and end day of ADCP measurement.
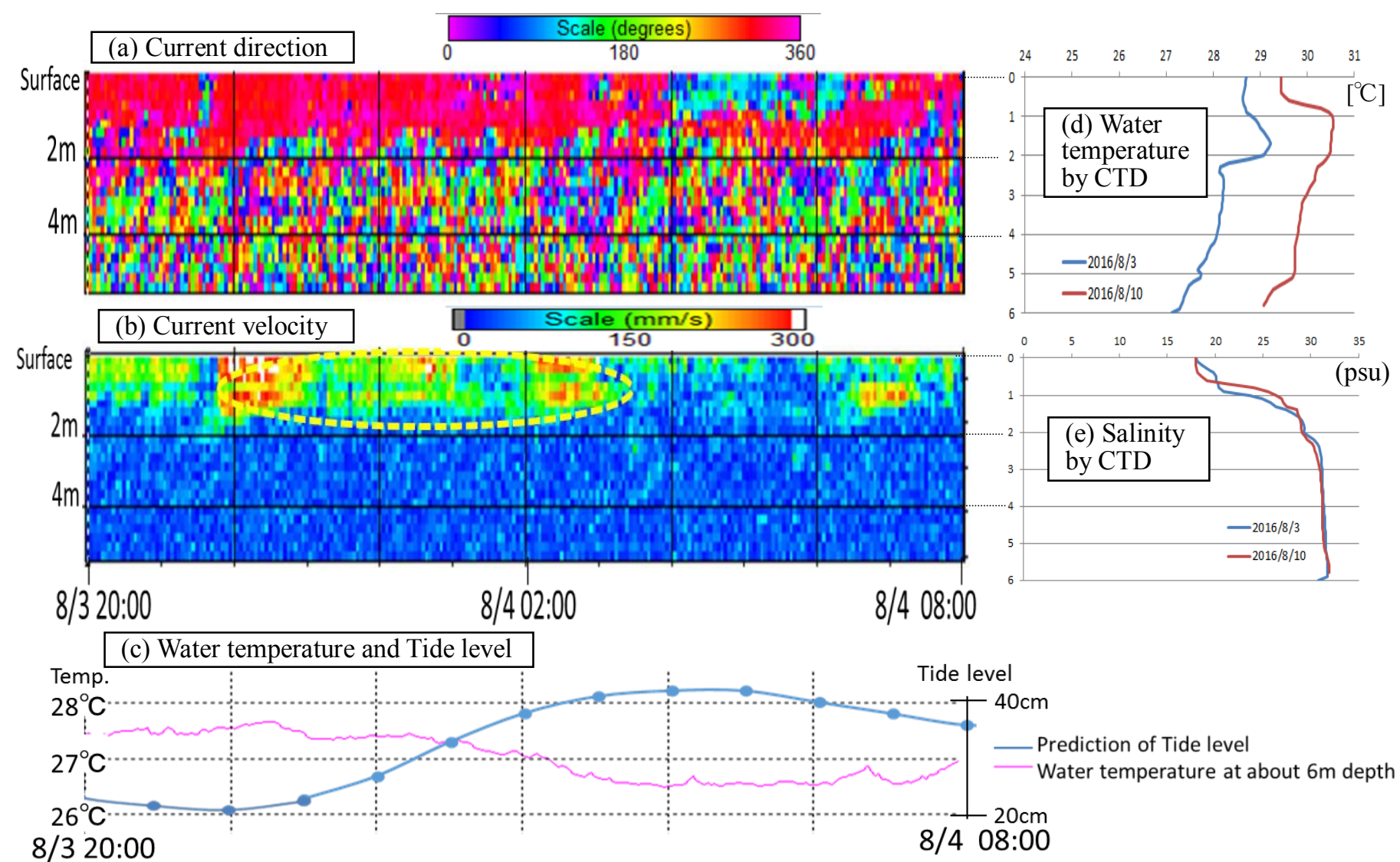

$8 / 320: 00$

Fig.5 (Left) Measured results of ADCP, (a) Current direction, (b) Current velocity and (c) Water temperature, compared with predicted water level by Japan Metrological Agency (JMA) ${ }^{(5)}$, Aug. 03-04, 2016. (Right) Vertical profiles of (d) Water temperature and (e) Salinity by CTD measurement on Aug. 03 and 04, 2016, start and end day of ADCP measurement. 
握は、Fig.4 に示すレベルが限界と言える。

そこで、ADCP に設置されている温度センサー

（水深約 $6 \mathrm{~m}$ ）の計測值と、富山新港の水位予測 を、Fig.5 (c) で比較してみると、Fig.4 (c) と同様 に干潮時に水温が上がり、満潮時に水温が下がる といった現象が確認できた。これは、底部まで高 温となっている水塊に、外海から温度の低い海水 が浸入することにより起こる現象と思える。ここ で、流速が約 $5 \mathrm{~cm} / \mathrm{s}$ 以下と非常に弱い状況である が、干潮から満潮において、東向きの流入が存在 することが確認された。そして、この水温低下が 起こっている、干潮から満潮へ向から、3 日 22 時 から4 日 2 時の時間帯では、(b) Current velocity の 表層の黄色点線丸印で囲った範囲で、流速が約 0.2 〜0.3m/s に上がっていることが分かる。

こうして、この8 月の観測時においても、水路端部に おいて、下層の東向きの流れに、表層の軽い水塊が 押されている循環が発生していることが推則できる。

\section{3.流れの発生する現象についての考察}

2 章で示した観測より、当研究で対象としてい る水域は、表層は河川水、その下層は外海と同密 度でつながる海水影響が大きく、その間に混合層 がある。この各層において、風、潮流、水塊の密 度差等が要因となり、各層で異なる流れが発生し ていることが確認できた。そして冬季と春・夏季

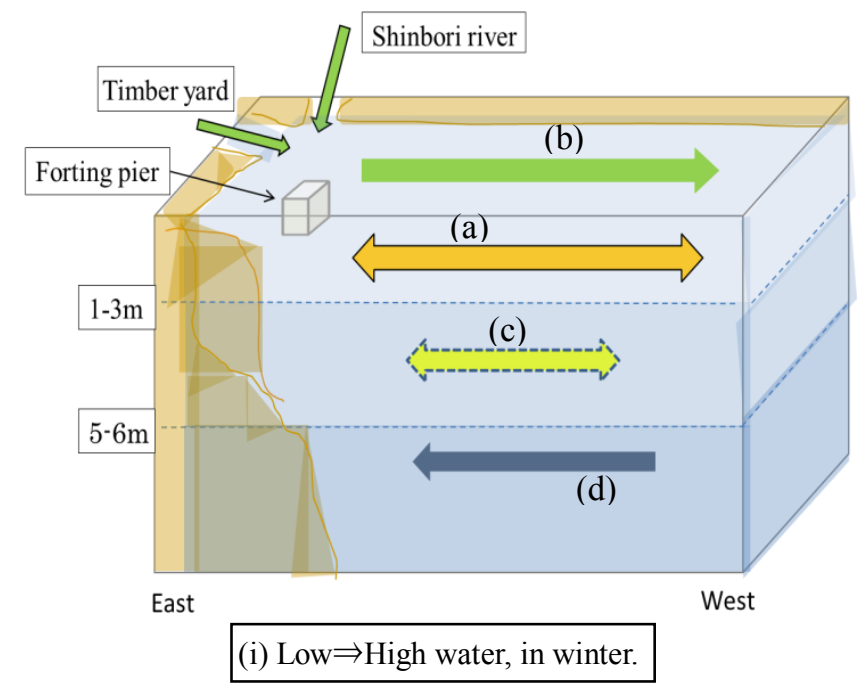

(a) Surface flow, influenced by weather and sea condition.

(The influence by swell is notable in winter.)

(b) Inflow from timber yard and Shinbori River.

(c) Unstable flow, in mixed water layer.

(d) Tidal current, below about 5 $6 \mathrm{~m}$ depth.
では、この 3 層の境界位置が変化することを確認 した。Fig.6に、こうした観測結果から推測できる、 ここで起こる流れの発生機構について、冬季と 春・夏季、干潮から満潮時の上潮が東向きとなる 場合について示した。

冬季の場合、水塊の境界は約 $1 \sim 2 \mathrm{~m}$ 深と 5～6m 深であり、表層部は貯木場・新堀川からの低塩分 水の流入により西向きの流れ（Fig.6の(a)）が発生 するが、冬季の季節風や富山湾では定常的に発生 しているうねりの侵入の影響で、この西向きの流 れがハッキリしない場合が多い（Fig.6の(b)）。中 層部の流れは不安定であり（Fig.6の(c)）、下層部 は、約 $0.05 \sim 0.1 \mathrm{~m} / \mathrm{s}$ 以下の弱い流速であるが、潮 汐影響により干潮から満潮では東向きの流れが発 生している（Fig.6の (d))。

春・夏季では、水塊構造の境界は約 1～2m と 4 〜 $5 \mathrm{~m}$ の 3 層構造になっている。まず、表層部は、 気温上昇と河川水量の増加のために、高温・低塩 分の密度が低い状態で成層している。この成層は、 夏季には非常に強くなる。そして、こうして成層 した水塊が、栈橋から東側の浅水域に溜まってお り、これが西方に流れ出ていると考えられる

(Fig.6の(e))。ここが浅海域であるのは、土砂が 堆積しやすい場所であるので、流入してくる河川 水が澱む状況であることが伺える。この下層では、 干潮から満潮の場合は東向き流れが発生している

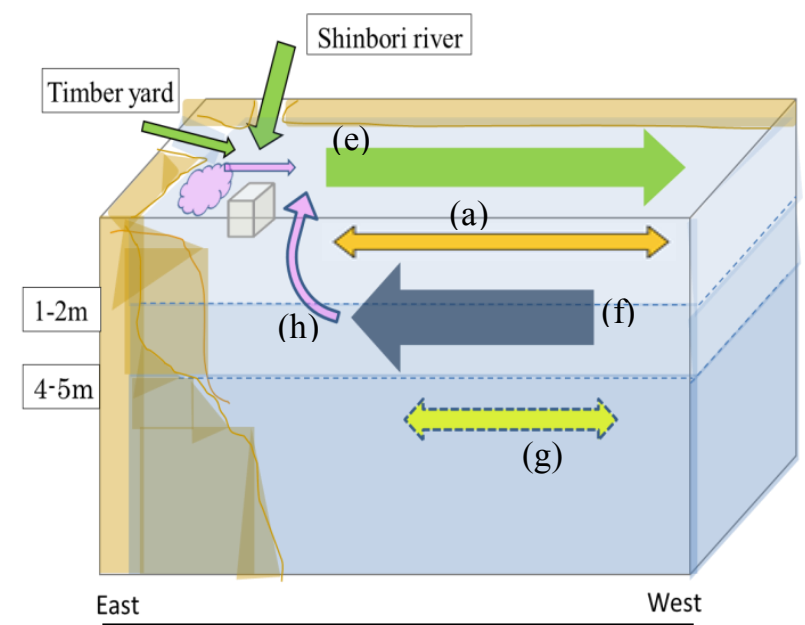

(ii) Low $\Rightarrow$ High water, in spring and summer.

(e) The low-density flows by river water inflow, and the water is stagnated in shallow water area and veer west.

(f) Tidal current, below about 1 $2 \mathrm{~m}$ depth.

(g) Unstable flow, under tidal current water layer.

(h) Upward flow by change of water depth.

Fig.6 The estimated vertical current structures in winter and summer, from the observation results in this study, at the case of Low $\Rightarrow$ High water. 
(Fig.6の(f))。約 4〜 5m 以深では、流れは不安定 となっている（Fig.6の $(\mathrm{g})$ )。ここで、干潮から満 潮の場合、この潮流の流れが、水深が急に浅くな る浮栈橋近辺において、上方に行き、上層部の密 度の低い水塊を押し出し（Fig.6の(h)）、表層の西 向きの勢力が強くなると考えられる。

\section{4. おわりに}

この春から夏場に顕著となる西向きの流れは、 上層が低密度で成層する時期に発生しやすい現象 である。そして、下層で干潮から満潮に伴う東向 きの流れがあり、これが地形性効果で港の東端部 で上方に行き、上層部の西向きの流れの勢力を増 加させる。これにより、カッター航行や、大型船 の離着栈橋に影響を受けるような、約 $0.1 \sim 0.3 \mathrm{~m} / \mathrm{s}$ の流れが発生すると推測できた。

ここで、日本海特有の $10 \sim 20 \mathrm{~cm}$ 程度の小さい 潮高差による弱い潮汐流でも、こうした流れに強 い影響力を与えていることもわかった。

今後は、続けて観測及びデータ分析を実施し、 流れの発生条件をより明確にしていき、この予測 技術の確立にも展開していきたい。特に、今回の 観測では、考察まで至らなかった、満潮から干潮 時における、表層から下層における、流れの構造 と発生メカニズムを解明していきたい。また、こ うした流れの水平的な分布についても把握したい。 今回の観測と考察で得た知見より、浮栈橋付近 で上層と下層の水温と塩分状況の連続モニタリン グを実施すれば、こうした流れの現象を予測する ことが可能である。この観測を複数点のネットワ ークで行えれば、より有効であると思える。既に、 こうしたシステムの構築(7)にも取り組んでいる。 また、こうした現象は、日本全国の各地の港で 発生していると思える。全長が $100 \mathrm{~m}$ 超えるよう な大型船の場合、入港時に岸壁や係留ブイに近づ く際、接岸スピードは $3 \sim 6 \mathrm{~cm} / \mathrm{s}$ であり ${ }^{(8)}$ 、微速の 流れでも大きく影響するものである。ベテランの 水先人の事例報告(9)では、港内での予測しない局 所的な流れが、操船に影響を与えた事例が多くあ るが、ここで港内における河川水の影響が大きい ことが指摘されている。具合的な事例としては、 名古屋港入港の際、航路の予測潮流は東向きだっ たにも関わらず、河川の近くにある目的のブイ周 辺になると、西向きに流され、ブイに近づくこと が困難だったことが報告されている(10)。また、大
型船の微速操船では、上層と下層の流れが違う状 況を考慮することの必要性も提言されている(11)。 本研究では、こうした大型船の入港操船やシミ ユレータ訓練の設定に、有効な情報を提供してい けるようにも努めていきたい。

\section{5. 謝辞}

富山高等専門学校の臨海実習場技術職員の皆様、 平成 28 年度商船学科卒業生の池畑裕太郎学生と 藤澤映歩学生には、観測に多大にご協力を頂き、 ここに謝意を表します。本研究の一部は(公財)環 日本海環境協力センターの「富山湾プロジェクト」、 平成 26 年度採択の科学研究費補助金(15K06625) 「河川水と海流が複合影響を及ぼす沿岸域におけ る海水構造・流動の特性把握」によるものです。

\section{6. 参考文献}

(1) 千葉元・道田豊・古山彰一・橋本心太郎：「船 舶搭載型 ADCP で捉えられた富山湾の流れの 特性一夏期湾奥部で発生する反時計回りの渦 について一」, 海洋調查技術 27(2), pp.1-14, 2015.9.

(2) 千葉元・浜田健史・道田豊・橋本心太郎：「船 舶搭載型 $\mathrm{CTD} ・ \mathrm{ADCP}$ による富山湾の海洋環 境調査」, 日本航海学会論文集 132, pp. 86-96, 2015.7.

（3）（公財）環日本環境協力センター：「平成 27 年度環境省請負事務 北西太平洋地域海行動 計画活動推進事業報告書」, (公財) 環日本海 環境協力センター, 2016.3

(4) 宇野木早苗 :「海の自然と災害」,成山堂書店, pp.229-234, 2014.6.

(5) 気象庁 HP • 潮位表 : http://www.jma.go.jp

(6) 千葉元・古山彰一・道田豊：「海底設置型 $1200 \mathrm{kHz}$ ADCP を用いた極沿岸域の流れ場計 測」, 日本海洋学会 2014 年度春季大会 118 , 2014.3.

(7) Masashi Yoshida, Hajime Chiba and Yuki Kanda, "WSN Using the Small Buoy for 3-D mapping of a Coastal Area", IS-GNSS, 2015.11.

(8) 近藤信夫・今西邦彦：「瀬戸内海の気象と海象 第 6 部 瀬戸内海の水先案内」: 海洋気象学会, pp.195-209, 2013.1.

(9) 石畑崔郎:「操船実学」, 成山堂書店, 2006.4

(10) 同上 p.4 (11) 同上 p.275 